\title{
AGROSAINSTEK
}

Jurnal Ilmu dan Teknologi Pertanian

Website jurnal : http://journal.ubb.ac.id/index.php/agrosainstek

Artikel Penelitian

\section{Potensi Pseudomonas sp. untuk Mengendalikan Penyakit Hawar Daun Bakteri (Xanthomonas oryzae pv. Oryzae) Secara In Vitro}

\section{The Potential of Pseudomonas sp. in Controlling Bacterial Leaf Blight Disease (Xanthomonas oryzae pv. oryzae) by In Vitro}

\author{
Andree Saylendra ${ }^{*}$, Nurmayulis ${ }^{1}$, Pina Ahdiani1 ${ }^{1}$ \\ 1 Jurusan Agroekoteknologi Universitas Ageng Tirtayasa \\ Jl. Raya Jakarta Km 4 Serang Banten
}

Diterima : 17 April 2016/Disetujui : 10 Januari 2017

\begin{abstract}
This research was aimed to determine potential of Pseudomonas sp. in controlling bacterial leaf blight disease (Xanthomonas oryzae pv. oryzae) in vitro. This research was conducted at the Laboratory of Agroecology, Faculty of Agriculture, University of Sultan Ageng Tirtayasa on June to September 2014. This research implemented experimental one factor that arranged in Completely Randomized Design with five replications. The treatment consisted of 6 isolates of Pseudomonas sp. (Ps 6, Ps 29, Ps 39, Ps 40, Ps 45, dan Ps 46) which was screened from rhizosper of roots of paddy plants. The inhibition of Pseudomonas sp. bacteria isolates was tested and showed that the results were not significantly different neither it was between each isolates nor against control (without treatment bacteria). Ps 39 isolate tend to had higher clear zone compare to other isolates.
\end{abstract}

Keywords: Pseudomonas sp., in vitro, rhizosper, screening, Xanthomonas oryzae pv. oryzae.

ABSTRAK

Tujuan penelitian ini untuk mengetahui potensi Pseudomonas sp. asal rhizosper padi sebagai agen hayati untuk mengendalikan penyakit hawar daun bakteri (Xanthomonas oryzae pv. oryzae) secara in vitro. Penelitian dilaksanakan di Laboratorium Agroekoteknologi, Fakultas Pertanian, Universitas Sultan Ageng Tirtayasa pada bulan Juni-September 2014. Penelitian menggunakan rancangan acak lengkap non faktorial dengan lima ulangan. Perlakuan terdiri dari 6 isolat Pseudomonas sp. (Ps 6, Ps 29, Ps 39, Ps 40, Ps 45, dan Ps 46) yang memiliki kemampuan antagonis dan 1 kontrol air (tanpa bakteri) sebagai pembanding, sehingga terdapat 35 satuan percobaan. Isolat-isolat bakteri Pseudomonas sp. yang diuji daya hambatnya secara analisis tidak memiliki pengaruh, baik antar isolat maupun terhadap kontrol (tanpa bakteri perlakuan). Namun, secara keseluruhan mempengaruhi yaitu dengan terbentuknya zona bening menunjukkan adanya tingkat pengendalian. Isolat-isolat bakteri Pseudomonas sp. memiliki kemampuan yang relatif sama dalam mengendalikan bakteri Xanthomonas oryzae pv. oryzae. Meski demikian, isolat Ps 39 dan memiliki zona bening yang cenderung lebih tinggi.

Kata kunci: Pseudomonas sp., in vitro, rhizosper, skrining, Xanthomonas oryzae pv. oryzae.

\section{Pendahuluan}

Serangan penyakit bacterial leaf blight atau hawar daun bakteri di Indonesia pada tahun 2013

*Korespondensi Penulis.

E-mail: andree20s@yahoo.com (A. Saylendra) mencapai 25.475 ha. Pada tahun 2014, penyakit ini diperkirakan menyerang lahan persawahan di Indonesia seluas 15.362 ha. Penyerangan di provinsi Banten diperkirakan mencapai 1.061 ha (Balai Besar Peramalan Organisme Pengganggu Tumbuhan, 2014). Kerusakan secara kuantitatif akibat penyakit ini adalah turunnya hasil panen dan 
rendahnya bobot 1.000 biji, sedangkan kerusakan secara kualitatif ditunjukkan oleh tidak sempurnanya pengisian gabah dan gabah mudah pecah pada saat digiling. Kerusakan berat dapat mencapai lebih dari 50\%. Penurunan hasil padi akibat hawar daun bakteri umumnya berkisar antara 15-23\% (Kadir, 2009).

Upaya pengendalian hawar daun bakteri di dunia terkendala oleh kemampuan patogen untuk membentuk strain baru yang lebih virulen sehingga teknologi pencarian varietas yang tahan terhadap hawar daun bakteri menjadi kurang efektif. Sementara itu, penggunaan pestisida berupa bahan kimia antibakteri diketahui dapat menyebabkan gangguan pada kesehatan manusia dan lingkungan karena meninggalkan residu (Wahyudi et al., 2011).

Penggunaan agen hayati diharapkan dapat menjadi salah satu alternatif dalam pengendalian penyakit tersebut yang aman dan tidak mencemari lingkungan. Pada umumnya jenis agen hayati yang dikembangkan adalah mikroba alami, baik yang hidup sebagai saprofit di dalam tanah, air dan bahan organik, maupun yang hidup di dalam jaringan tanaman yang bersifat menghambat pertumbuhan dan berkompetisi dalam ruang dan nutrisi dengan patogen sasaran. Diantara kelompok agens hayati tersebut bakteri Pseudomonas sp. merupakan salah satu yang menempati urutan teratas paling banyak digunakan dan diteliti (Supriadi, 2006).

Berdasarkan hasil penelitian, bakteri Pseudomonas aeruginosa dan Pseudomonas diminuta mampu menghambat pertumbuhan Xanthomonas oryzae pv. oryzae secara in vitro (Agustiansyah et al., 2013). Ciri utama Pseudomonas spp. yang membuatnya sesuai sebagai agen pengendalian hayati penyakit tanaman diantaranya dapat tumbuh dengan cepat pada sediaan in vitro untuk produksi massal, menghasilkan pigmen pendarfluor yang manjadi bahan baku bioaktif berspektrum lebar (misalnya, antibiotik, siderofor, senyawa volatil, dan fitohormon), bersaing agresif dengan mikroorganisme lain, dan mampu menyesuaikan diri terhadap tekanan lingkungan (Weller, 2007).

Berdasarkan uraian di atas, maka perlu dilakukan penelitian mengenai potensi bakteri Pseudomonas sp. untuk mengendalikan penyakit hawar daun bakteri (Xanthomonas oryzae pv. oryzae).

\section{Bahan dan Metode}

Penelitian dilaksanakan di Laboratorium Agroekoteknologi Fakultas Pertanian Universitas Sultan Ageng Tirtayasa pada bulan Juni 2014 sampai dengan September 2014. Isolat bakteri
Xanthomonas oryzae pv. oryzae adalah isolate koleksi laboratorium Agroekologi Faperta Untirta.

Penelitian ini menggunakan Rancangan Acak Lengkap 1 faktor yang terdiri dari 7 taraf yaitu 6 isolat bakteri dan 1 kontrol sebagai pembanding. Perlakuan diulang sebanyak 5 kali, sehingga menghasilkan 35 satuan percobaan. Perlakuan tersebut digunakan dalam pengaplikasian pada skrining II untuk diuji daya hambatnya dengan mengukur diameter zona bening yang terbentuk.

\section{Isolasi Bakteri Pseudomonas sp.}

Bakteri Pseudomonas sp. Diisolasi dari rhizosper perakaran padi dari daerah Terumbu Kecamatan Kasemen Kota Serang. Tanah beserta perakaran diambil dari perakaran tanaman padi, ditimbang sebanyak $10 \mathrm{~g}$ dan dimasukkan ke dalam erlenmeyer $250 \mathrm{ml}$, disuspensikan dengan $90 \mathrm{ml}$ air steril $\left(10^{-1}\right)$ kemudian dikocok dengan menggunakan shaker selama 30 menit. Selanjutnya diambil $1 \mathrm{ml}$ dari suspensi tersebut menggunakan mikropipet dan dimasukkan ke dalam tabung reaksi, setelah itu disuspensikan dengan air steril sebanyak $9 \mathrm{ml}\left(10^{-2}\right)$, diaduk dengan vortex selama 1 menit, pengenceran berikutnya $\left(10^{-3}\right.$ sampai $10^{-}$ 12) dilakukan dengan cara yang sama. Pada pengenceran $10^{-5}$ sampai $10^{-12}$ suspensi tersebut masing-masing diambil $0.5 \mathrm{ml}$ untuk ditumbuhkan pada cawan petri berisi $10 \mathrm{ml}$ media Pseudomonas Agar Base disebarkan dan diratakan dengan menggunakan batang L, kemudian diinkubasi selama 24-48 jam pada suhu ruang. Media Pseudomonas Agar Base merupakan media selektif guna mempermudah mendapatkan bakteri Pseudomonas sp. Bakteri yang tumbuh pada umur 1-2 hari memiliki ciri koloni berbentuk bulat, pinpoint, dan berwarna putih keruh.

Koloni-koloni bakteri Pseudomonas sp. yang terbentuk diambil dan diisolasi dengan menggunakan jarum ose kemudian diinokulasi secara goresan ke dalam media Pseudomonas Agar Base pada cawan petri, diinkubasi selama 48 jam pada suhu ruang. Kemudian diisolasi kembali pada media Pseudomonas Agar Base untuk mendapatkan isolat murni dari bakteri Pseudomonas sp.

\section{Penapisan Bakteri (Skrining I)}

Penapisan bakteri atau skrining I dilakukan untuk memilih beberapa isolat koloni bakteri Pseudomonas sp. yang diduga memiliki potensi daya antagonis sebagai agen pengendali hayati patogen Xanthomonas oryzae pv. oryzae. Inokulum bakteri patogen Xanthomonas oryzae pv. oryzae dibuat yaitu satu petri isolat murni bakteri patogen Xanthomonas oryzae pv. oryzae yang berumur 2 hari 
ditambahkan dengan $10 \mathrm{ml}$ air steril, kemudian diaduk rata dengan pengaduk batang L. Larutan Xanthomonas oryzae pv. oryzae diambil sebanyak $0.1 \mathrm{ml}$, diinokulasi pada media TSA dengan metode spread plate yaitu menyebarkannya pada permukaan media di cawan petri, diratakan dengan menggunakan batang L, dan dibiarkan suspensi bakteri patogen tersebut meresap ke dalam media agar. Kemudian bakteri Pseudomonas sp. dari isolat koloni bakteri yang berbeda digoreskan pada empat sisi yang berlawanan dalam media yang telah diinokulasikan bakteri patogen sebelumnya (untuk 1 cawan petri). Cara yang sama dilakukan hingga isolat koloni bakteri Pseudomonas sp. yang didapat teraplikasikan semua. Selama 24-48 jam diamati dengan melihat ada tidaknya zona bening.

Isolat bakteri Pseudomonas sp. yang membentuk zona bening atau adanya aktifitas antimikroba serta yang menyelimuti pertumbuhan koloni bakteri patogen merupakan bakteri yang berpotensi dalam mengendalikan bakteri patogen Xanthomonas oryzae pv. oryzae. Hasil skrining I dikategorikan menjadi 2 , yaitu tidak terbentuk zona bening (-) dan terbentuk zona bening (+). Bakteri yang berpotensi $(+)$ diuji daya hambatnya pada tahap skrining II.

\section{Skrining II}

Skrining II dilakukan dengan tujuan untuk mengetahui daya hambat yang terbaik dari beberapa bakteri antagonis Pseudomonas sp. terhadap bakteri patogen Xanthomonas oryzae pv. oryzae secara in vitro. Dimana Pseudomonas sp. yang digunakan merupakan bakteri yang memiliki potensi dalam menghambat bakteri patogen hasil dari skrining I. Pengujian daya hambat pada skrining II menggunakan metode Kirby-Bauer atau biasa disebut dengan metode difusi kertas cakram.

Pembuatan inokulum bakteri patogen Xanthomonas oryzae pv. oryzae yaitu satu petri isolat murni bakteri patogen Xanthomonas oryzae pv. oryzae yang berumur 2 hari ditambah dengan 10 $\mathrm{ml}$ air steril, kemudian diaduk rata dengan pengaduk batang L. Ambil $0.1 \mathrm{ml}$ larutan Xanthomonas oryzae pv. oryzae, inokulasikan pada media TSA dengan metode spread plate yaitu menyebarkannya pada permukaan media di cawan petri, diratakan dengan menggunakan batang L, dan suspensi bakteri patogen tersebut dibiarkan meresap ke dalam media agar.

Penyiapan bakteri uji, yaitu satu isolat Pseudomonas sp. pada cawan petri disuspensikan dengan akuades sebanyak $10 \mathrm{ml}$, kemudian diaduk dan diratakan menggunakan batang L. Kertas cakram dicelupkan ke dalam larutan bakteri antagonis Pseudomonas sp. Kertas cakram yang digunakan, sebelumnya disterilisasi terlebih dahulu dalam oven pada suhu $80^{\circ} \mathrm{C}$.

Kertas cakram yang telah berisi larutan bakteri didiamkan selama 15 menit sebelum diletakkan pada media uji. Kemudian, kertas cakram diletakkan di tengah permukaan media yang telah berisi bakteri patogen Xanthomonas oryzae pv. oryzae dan diinkubasi pada suhu ruang (Noverita et al., 2009). Pengamatan dilakukan selama tujuh hari, dengan cara mengukur diameter zona hambat atau zona bening yang terbentuk.

\section{Parameter Pengamatan (Lebar Zona Bening)}

Pengamatan lebar zona bening dilakukan untuk melihat kemampuan bakteri antagonis dalam menghambat pertumbuhan bakteri patogen pada skrining II yaitu dengan mengukur diameter lingkaran zona bening yang terbentuk di sekitar kertas cakram. Zona bening yang terbentuk karena adanya daya antibakteri, diukur dari sisi sebelah kiri sampai sisi sebelah kanan dengan menggunakan penggaris (Melki et al., 2011) kemudian dikurangi dengan diameter kertas cakram. Diameter zona bening diukur sebanyak empat kali dari sisi yang berbeda dalam tiap cawan, kemudian direrata.

\section{Hasil}

Hasil eksplorasi bakteri Pseudomonas sp. dari tanah beserta akar tanaman padi yang berasal dari daerah Unyur Kecamatan Kota Serang, terdapat 54 isolat bakteri Pseudomonas sp. yang berhasil diisolasi dalam media Pseudomonas Agar Base. Isolat-isolat tersebut digunakan pada tahap skrining I untuk mendapatkan bakteri yang bersifat antagonis terhadap patogen. Pada tahap ini, terdapat 13 isolat yang memiliki kemampuan antagonis yaitu dengan terbentuknya zona bening di sekitar bakteri Pseudomonas sp. yang digoreskan pada media yang sebelumnya telah disebar bakteri patogen Xanthomonas oryzae pv. oryzae. Namun dari 13 isolat tersebut hanya 6 isolat terbaik yang digunakan pada tahap skrining II.

Berdasarkan hasil sidik ragam pada skrining II, lebar zona bening yang terbentuk oleh Pseudomonas sp. dalam mengendalikan Xanthomonas oryzae pv. oryzae secara in vitro menunjukkan tidak adanya pengaruh. Rerata lebar zona bening yang terbentuk oleh Pseudomonas sp. dalam mengendalikan Xanthomonas oryzae pv. oryzae disajikan pada Tabel 1.

Isolat-isolat bakteri Pseudomonas sp. (Ps 6, Ps 29 , Ps 39, Ps 40, Ps 45, dan Ps 46) yang diuji daya hambatnya secara analisis tidak adanya pengaruh baik antar isolat maupun terhadap kontrol (tanpa 
bakteri perlakuan), namun secara keseluruhan mempengaruhi yaitu dengan terbentuknya zona bening menunjukkan adanya tingkat pengendalian. Isolat-isolat bakteri Pseudomonas sp. tersebut memiliki kemampuan yang relatif sama dalam mengendalikan bakteri Xanthomonas oryzae pv. oryzae. Meski dikatakan memiliki kemampuan yang relatif sama, isolat Ps 39 memiliki nilai rerata cenderung lebih tinggi dengan lebar $0,78 \mathrm{~mm}$ (Gambar 1). Zona bening yang terbentuk di sekitar bakteri Pseudomonas sp. tersebut menunjukkan adanya sifat antagonis.

Tabel 1. Lebar zona bening bakteri Pseudomonas sp. dalam mengendalikan bakteri Xanthomonas oryzae pv. oryzae.

\begin{tabular}{cc} 
Kode Isolat & $\begin{array}{c}\text { Rerata Lebar Zona Bening } \\
(\mathbf{m m})\end{array}$ \\
\hline Tanpa bakteri & 0 \\
Ps 6 & 0.65 \\
Ps 29 & 0.44 \\
Ps 39 & 0.78 \\
Ps 40 & 0.36 \\
Ps 45 & 0.69 \\
Ps 46 & 0.54 \\
\hline
\end{tabular}

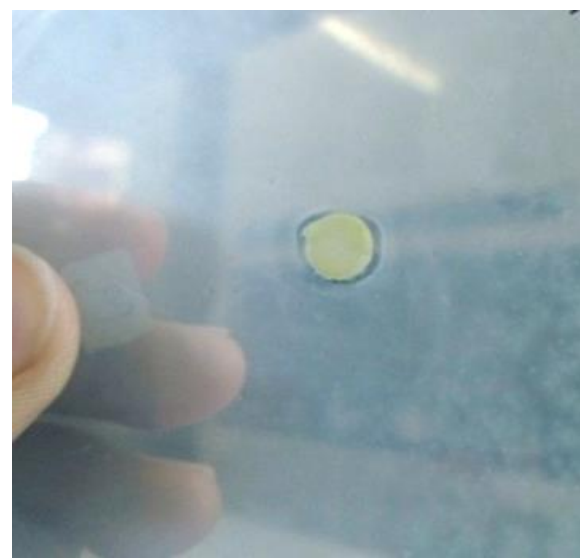

Gambar 1. Zona bening yang terbentuk hasil skrining II pada pemberian isolat Ps 39

Kertas cakram yang telah mengandung bakteri diletakkan pada agar yang mengandung bakteri patogen. Konsentrasi menurun sebanding dengan luas bidang difusi. Zat antimikroba terdifusi sampai pada titik zat tersebut tidak lagi menghambat pertumbuhan bakteri patogen. Efektifitas antimikroba ditunjukkan oleh zona hambatan yang tampak sebagai area jernih atau bening yang mengelilingi kertas cakram tempat zat dengan aktifitas antimikroba terdifusi (Harmita dan Radji, 2008).

\section{Pembahasan}

Hasil penelitian menunjukkan 6 isolat Pseudomonas sp. memberikan pengaruh yang tidak nyata terhadap kontrol, karena lebar zona bening yang terbentuk sangatlah kecil. Hal tersebut dapat disebabkan karena beberapa faktor. Ukuran zona hambatan dapat dipengaruhi oleh kepadatan atau viskositas media biakan, kecepatan difusi zat antimikroba, konsentrasi pada kertas cakram, sensitifitas organisme terhadap zat antimikroba, dan interaksi zat antimikroba dengan media (Harmita dan Radji, 2008). Produksi antibiotika yang merupakan salah satu anti mikroba dipengaruhi oleh faktor lingkungan yaitu nutrisi, jenis medium, kedalaman agar, umur biakan, jumlah inokulum dan suhu (Soesanto et al, 2010., Soesanto et al, 2011). Nutrisi merupakan faktor utama, dimana bakteri antagonis hanya akan memproduksi antibiotik jika nutrisi dalam mikrohabitatnya melimpah (Purnomo, 2010). Pada penelitian ini, bahan media yang digunakan pada skrining II tidak full strength (40 g/L) namun setengahnya $(23 \mathrm{~g} / \mathrm{L})$, dalam kata lain nutrisi pada media yang digunakan tidak tinggi.

Selain nutrisi, kesensitifan organisme terhadap zat antimikroba dapat juga menjadi salah satu alasan. Bakteri Xanthomonas oryzae pv. oryzae merupakan bakteri gram negatif yang memiliki susunan dinding selnya terdiri atas lipopolisakarida, membran luar, lipoprotein dan peptidoglikan yang berada dalam ruang periplasma. Menurut Kusuma (2012) dalam penelitiannya, membran luar yang merupakan struktur berlapis ganda, lapisan sebelah dalamnya memiliki komposisi yang serupa dengan membran sitoplasma, sedangkan lapisan sebelah luar diisi oleh lipopolisakarida. Adanya membran luar ini menyebabkan bakteri Gram negatif lebih resisten terhadap zat antimikroba karena membran luar menghalangi masuknya senyawa antimikroba yang umumnya memiliki berat molekul besar. Ruang periplasma adalah ruang antara membran dalam dan membran luar. Pada protein periplasma terdapat enzim pendetoksifikasi yang dapat menonaktifkan zat mikroba tertentu.

\section{Kesimpulan}

Isolat-isolat bakteri Pseudomonas sp. memiliki kemampuan yang relatif sama dalam mengendalikan bakteri Xanthomonas oryzae pv. oryzae. Meski demikan, isolat Ps 39 memiliki zona bening yang cenderung lebih tinggi dibanding dengan isolat lainnya. 


\section{Daftar Pustaka}

Agustiansyah, Satriyas I, Sudarsono, Muhammad M. 2010. Pengaruh Perlakuan Benih secara Hayati pada Benih Padi Terinfeksi Xanthomonas oryzae pv. oryzae terhadap Mutu Benih dan Pertumbuhan Bibit. Jurnal Agronomi Indonesia 38 (3) : 185-191.

Balai Besar Peramalan Organisme Pengganggu Tumbuhan. 2014. Buletin Peramalan OPT. Vol. 13, No. 1, 2014: 4-5.

Harmita, Maksum R. 2008. Buku Ajar Analisis Hayati. Penerbit Buku Kedokteran EGC. Jakarta. Hal: 1-2.

Kadir TS. 2009. Menangkal HDB dengan Menggilir Varietas. Balai Besar Penelitian Tanaman Padi. Sukamandi. Warta Penelitian dan Pengembangan Pertanian, Vol. 31, No. 5.

Kusuma R. 2012. Analisis Ekstrak Kulit Kayu Meranti Merah (Shorea leprosula Miq.) Sebagai Bahan Antibakteri Terhadap Bakteri Escherichia coli. Mulawarman Scientifie. Vol. 11 No. 1: 111-124.

Purnomo H. 2010. Pengantar Pengendalian Hayati. ANDI. Yogyakarta. 198 hal.

Supriadi. 2006. Analisis Risiko Agens Hayati untuk Mengendalikan Patogen Tanaman. Balai
Penelitian Tanaman Obat dan Aromatik. Bogor.

Soesanto L, Endang M, Ruth FR. 2010. Kajian Mekanisme Antagonis Pseudomonas fluorescens P60 terhadap Fusarium oxysporum F.Sp. Lycopersici pada Tanaman Tomat In Vivo. Jurnal HPT Tropika. Vol.10, No.1: 108-115.

Soesanto LE, Mugiastuti, Rahayuniati RF. 2011. Morphological and Physiological features of Pseudomonas fluorescens P60. Journal 4th International Seminar of Indonesian Society for Microbiology. Pages 22-24.

Wahyudi AT, Siti M, Abdjad A. 2011. Xanthomonas Oryzae pv. oryzae Bakteri Penyebab Hawar Daun Pada Padi: Isolasi, Karakterisasi, dan Telaah Mutagenesis dengan Transposon. Makara, Sains. Vol. 15 No. 1: 89-96.

Weller DM. 2007. Pseudomonas Biocontrol Agents of Soilborne Pathogens: Looking Back Over 30 Years. Phytopathology. Department of Agriculture-Agricultural Research Service, Root Diseaseand Biological Control Research Unit, Washington State University. U.S. Vol. 97 No. 2: 251-256. 